Asian Australas. J. Biosci. Biotechnol. 2020, 5 (2), 72-77

Asian-Australasian Journal of

Bioscience and Biotechnology

ISSN 2414-1283 (Print) 2414-6293 (Online)

www.ebupress.com/journal/aajbb

\title{
Article \\ Growth and reproductive performances of Hilly Brown Bengal goat under semi- intensive management condition at Naikhongchari hilly areas of Bangladesh
}

\author{
Md. Ashadul Alam ${ }^{1 *}$, Md. Ershaduzzman ${ }^{2}$, Razia Khatun ${ }^{2}$, Md. Azharul Islam Talukder ${ }^{2}$ and Nathu Rum \\ Sarker $^{2}$ \\ ${ }^{1}$ Bangladesh Livestock Research Institute, RS, Naikhongchari, Bandarban, Bangladesh \\ ${ }^{2}$ Bangladesh Livestock Research Institute, Savar, Dhaka-1341, Bangladesh \\ *Corresponding author: Md. Ashadul Alam, Senior Scientific Officer, Bangladesh Livestock Research Institute, \\ RS, Naikhongchari, Bandarban, Bangladesh. Phone: +8801710480541; E-mail: apple_bau118@yahoo.com
}

Received: 23 July 2020/Accepted: 19 August 2020/ Published: 31 August 2020

\begin{abstract}
The objective of the study was to evaluate the growth and reproductive performances of Hilly Brown Bengal (HBB) goats of different generations and conducted at Naikhongchari Regional Station Research Farm of Bangladesh Livestock Research Institute. Goats were reared in a plastic slated floor under semi-intensive system and were allowed to graze for 6-7 hours per day. Animals were given a concentrate mixture containing $17 \% \mathrm{CP}, 11 \mathrm{MJ} \mathrm{ME} / \mathrm{kg}$ DM provided twice daily in the morning and evening at the rate of $1 \%$ of their body weight. All goats were kept separately according to sex and age groups to avoid random mating. Natural mating program was performed to improve the economically important traits. Goats were de-wormed and diping on regular intervals and only PPR vaccine was given at the age of 2 months. Data on productive, reproductive and disease incidence of goat were recorded regularly and were analyzed. Results showed that Kid Birth Weight of HBB goats were significantly $(\mathrm{P}<0.01)$ differ among generations. Birth weight of $\mathrm{G}_{3}(1.21 \pm 0.013 \mathrm{~kg})$ was higher than $\mathrm{G}_{5}, \mathrm{G}_{4}, \mathrm{G}_{2}$ and $\mathrm{G}_{1}(1.11 \pm 0.01 \mathrm{~kg})$. Goat body weight of 3,6 and 9 months age were non-significant among generations. The age and weight at first conception were significantly $(\mathrm{p}<0.05)$ differ among generation. Age at first conception was lower of $\mathrm{G}_{4}\left(301.57 \pm 9.06\right.$ days) and higher of $\mathrm{G}_{1}(259.80 \pm 18.87$ days $)$ but body weight at first conception of $\mathrm{G}_{1}(12.23 \pm 0.47 \mathrm{~kg})$ was higher and $\mathrm{G}_{4}$ was lower $(10.65 \pm 0.52 \mathrm{~kg})$. Age at first kidding, gestation length and kidding interval was not significant $(\mathrm{P}>.05)$ effect on generations. Parity had no significant $(\mathrm{P}>.05)$ effect on kid birth weight but significantly $(\mathrm{p}<0.01)$ differ of Kid litter weight and litter size. According to birth type single kid was highest birth weight $(1.21 \pm 0.08 \mathrm{~kg})$ than double kid followed by triplet and quadruplet. Mortality percentage of HBB kids at the age of $0-90$ days were $13.08 \pm 0.23 \%$. It may be concluded that kid birth weight, age and weight at first conception of HBB goat were significantly $(\mathrm{P}<.05)$ affected on generation but age at first kidding, gestation length and kidding interval were non significantly $(\mathrm{P}<.05)$ affected.
\end{abstract}

Keywords; Hilly Brown Bengal goat (HBBG); growth; reproductive performance; Naikhongchari

\section{Introduction}

The majorities of the tribal people live in the Hilly forests with primitive ways of life. These regions possess slightly different type of genetic resources of livestock and poultry rather than the common indigenous. The priority should be given to increase the milk, meat and egg production from the available genetic resources of livestock through better management, feeding animal health and genetics. In this part, attempt has been taken to improve the production potentialities of the native genetic resources of livestock at Hilly regions. There are about 26.10 million goats in Bangladesh (DLS, 2018). Black Bengal Goat comprises more than $90 \%$ of the total goat population (Husain et al., 1998). Black Bengal goats bear variety of coat color, black, black and white, brown, brown and white and white coat color. Brown Bengal goat, a variety of Black Bengal goat, is available 
at the hilly districts of Bangladesh. They are reputed to be very hardy and capable of thriving in any adverse environmental condition. The Hilly Brown Bengal (HBB) goats are dwarf breed and are grazing top of the hills. They are known to be famous for its high adaptability, fertility, prolificacy, delicious meat and superior quality skin (Husain et al., 1998, Talukdar et al., 2014). In the hilly areas, goats are regarded as an intimate and integral part of rural farmers and most of the landless and marginal farmers own 1-5 goats and contribute economically to the subsistence farmers in mixed farming systems (Husain, 1993). Goat is also considered as the most promising livestock species for commercial meat (chevon) production. However, systematic information on growth and reproductive performance of HBB goats is very limited. These HBB goats are no doubt a promising treasure of Bangladesh but are going to be extinct. Thus, conservation and preservation of genetic resources as insurance against future needs has become a topic of mounting concern (Crowford, 1984). Therefore, the main objective of the study is to evaluate the growth and reproductive performances of HBB goats of different generation and their improvement and conservation at Naikhongchari.

\section{Materials and Methods}

\subsection{Location of the study}

The experiment was conducted at Bangladesh Livestock Research Institute Regional Station Research Farm which is located in Naikhongchari upazilla under Bandarban District.

\subsection{Feeding and rearing system}

The studied of HBB goats were maintained in a semi-intensive rearing system. Females were allowed to graze for 6 hours (from 9 AM to 3 PM) with 1-hour rest (1:00 PM to 2:00 PM). Kids up to three months of age were allowed to graze with their mother. Bucks were allowed to graze for 2 hours (from 7 AM to 9 AM) in morning and one hour in afternoon. Animals were given a concentrate mixture containing $17 \% \mathrm{CP}, 11 \mathrm{MJ} \mathrm{ME} / \mathrm{kg} \mathrm{DM}$ provided twice daily in the morning and evening at the rate of $1 \%$ of their body weight for different categories as pregnant and milking does, dry goats, growers, kids and bucks.

\subsection{Housing}

Goats were housed in a plastic slated floor of $1 \mathrm{~m}$ above from the ground. Bucks and bucklings were always kept separately from the does herd to avoid unplanned mating. Young kids were kept in a separate room with facilities for temperature control, feeding and watering provision and with adequate bedding materials during winter season. All goats were kept separately according to sex and age groups to avoid random mating.

\subsection{Breeding program}

Natural mating program was performed to improve the economically important traits. The physical sign of heat (barking, swelling and mucus discharge of vulva, jumping on other animal, off-feed) was observed with a buck every day morning. Female in estrous were mated with the buck naturally according to mating chart that has been planned previously.

\subsection{Health care and diseases}

Animals were vaccinated against PPR (Peste Des Petits Ruminants) for two times in a year. Kids were also vaccinated against PPR after two months of age. De-worming program was done every three month in a year and animals were dipped in $0.5 \%$ melatheon solution for each month. Necessary treatments were provided against specific diseases according to the suggestion of Veterinarian. Sick animals or kids, stunted growth, unthrifty condition and any severe skin diseases were also regularly treated and culled.

\subsection{Reproductive characteristics}

Data on productive, reproductive and disease incidence traits were recorded during 2015 to 2018. Reproductive traits studied were: litter size (LS), litter weight (LW), kid birth weight (KBW), gestation length (GL), age at first conception (AFC), age at first kidding (AFK) and kidding interval (KI). Mortality of HBB goat kids was also recorded. All the information about production and reproduction were recorded in an individual data sheet for each of the animal.

\subsection{Statistical analysis}

The statistical analysis of the data was performed using compare mean with one way ANOVA and univariate analysis of variance procedure of SPSS 17.0 package. The difference between treatments means were examined by using Duncan Multiple Range Test (DMRT). 
3. Results and Discussion

\subsection{Effect of generation on growth performance of $\mathrm{HBB}$ goats}

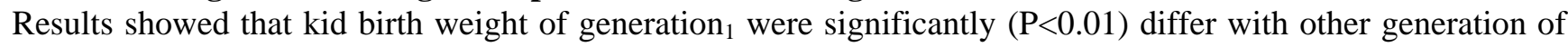
$\mathrm{G}_{2}, \mathrm{G}_{3}, \mathrm{G}_{4}$ and $\mathrm{G}_{5}$. Birth weight of $\mathrm{G}_{3}(1.21 \pm 0.013 \mathrm{~kg})$ was higher than $\mathrm{G}_{5}$,

$\mathrm{G}_{4}, \mathrm{G}_{2}$ and $\mathrm{G}_{1}(1.11 \pm 0.01 \mathrm{~kg}$ ) (Table 1). Jalil et al. (2016) reported that average birth weight of Black Bengal goat at generation , generation $_{1}$ and generation were $1.24 \pm 0.01,1.33 \pm 0.02$ and $1.32 \pm 0.04 \mathrm{~kg}$ respectively which is slightly higher than the present study. Akter et al. (2006) showed the average body weight at birth of Black Bengal goat was $0.96 \pm 0.04,1.02 \pm 0.08$ and $1.12 \pm 0.11 \mathrm{~kg}$ at $1^{\text {st }}, 2^{\text {nd }}$ and $3^{\text {rd }}$ generation respectively in selected group which is slightly lower than the findings. Result also showed that body weight of 3,6 and 9 months age of HBB goats were non-significant among generations (Table 1). Within breed, variation in birth weights is partly genetic, but largely due to variation within the environment, especially nutrition, management and health (Devendra and Burns, 1983). Body weight of $\mathrm{G}_{5}$ was higher at 3,6 , and 9 months of age than $\mathrm{G}_{1}, \mathrm{G}_{2}, \mathrm{G}_{3}$, and $\mathrm{G}_{4}$. Jalil et al. (2016) observed that the weaning weight were $5.15 \pm 0.37 \mathrm{~kg}, 5.34 \pm 0.16 \mathrm{~kg}, 4.87 \pm 0.39 \mathrm{~kg}$ and $4.17 \pm 0.14 \mathrm{~kg}$ at generation $1^{\text {st }}, 2^{\text {nd }}, 3^{\text {rd }}$ and foundation stock $\left(\mathrm{G}_{0}\right)$ respectively with average mean $4.88 \pm 0.07 \mathrm{~kg}$ which is slightly higher than the present study. Akter et al. (2006) also observed that the average weaning age is 3 months and their weight in selected groups of Black Bengal goat was $4.99 \pm 0.15,4.64 \pm 0.33$ and $4.07 \pm 0.42$ $\mathrm{kg}$ at $1 \mathrm{st}, 2 \mathrm{nd}$ and $3 \mathrm{rd}$ generation respectively which closely agrees with the study.

Table 1. Effect of generation on growth performance of hilly Brown Bengal goat.

\begin{tabular}{|l|l|l|l|l|}
\hline \multirow{2}{*}{ Generation } & \multicolumn{4}{|c|}{ Parameters (kg) } \\
\cline { 2 - 5 } & $\begin{array}{l}\text { Birth wt. } \\
(\text { Mean } \pm \text { SE) }\end{array}$ & $\begin{array}{l}\text { 3-m wt. } \\
(\text { Mean } \pm \text { SE) }\end{array}$ & $\begin{array}{l}\text { 6-m wt. } \\
(\text { Mean } \pm \text { SE) }\end{array}$ & $\begin{array}{l}\text { 9-m wt. } \\
\text { (Mean } \pm \text { SE) }\end{array}$ \\
\hline G-1 & $1.11^{\mathrm{b}} \pm 0.01(75)$ & $4.69 \pm 0.15$ & $7.12 \pm 0.28$ & $8.65 \pm 0.38$ \\
\hline G-2 & $1.16^{\mathrm{ab}} \pm 0.016(61)$ & $4.47 \pm 0.16$ & $7.07 \pm 0.29$ & $8.52 \pm 0.23$ \\
\hline G-3 & $1.21^{\mathrm{a}} \pm 0.013(51)$ & $4.71 \pm 0.15$ & $7.43 \pm 0.22$ & $9.68 \pm 0.32$ \\
\hline G-4 & $1.18^{\mathrm{a}} \pm 0.012(67)$ & $4.90 \pm 0.21$ & $7.21 \pm 0.32$ & $8.96 \pm 0.30$ \\
\hline G-5 & $1.20^{\mathrm{a}} \pm 0.031(23)$ & $5.03 \pm 0.24$ & $7.86 \pm 0.50$ & $9.15 \pm 0.85$ \\
\hline Sig. level & $* *$ & NS & NS & NS \\
\hline
\end{tabular}

Sig=Significance; $\mathrm{m}=$ month; $\mathrm{G}=$ Generation; Figure in the parenthesis indicates the number of observation. Means with different superscripts within the same column differ significantly. $* *=$ Significant at $1 \%(\mathrm{p}<0.01)$ level of probability, NS=Non significant $(\mathrm{p}>0.05)$.

\subsection{Effect of generation on reproductive traits of HBB goats}

From the Table 2, results showed that age at first conception were significantly $(p<0.05)$ differ among generations. Age at 1st conception was higher in $\mathrm{G}_{1}$ (259days) and lower in $\mathrm{G}_{4}$ (201 days). On the other hand, WFC were also significantly ( $\mathrm{p}<0.01$ ) differ among generations whereas WFC of $\mathrm{G}_{1}$ was slightly higher in $\mathrm{G}_{1}$ $\left(13.23 \mathrm{~kg}\right.$ ) than that of $\mathrm{G}_{2} \mathrm{G}_{3}$ and $\mathrm{G}_{4}(9.87 \mathrm{~kg}$ ) with an overall mean of $11.96 \mathrm{~kg}$. Chowdhury and Faruque (2001) has shown that the average age at 1st service of BBG goat as to be 10.98 months which was higher than that of the present findings. Jalil et al. (2016) observed that age at $1^{\text {st }}$ service was higher in $\mathrm{G}_{1}$ (212 days) than that in $\mathrm{G}_{2}$ (162 days) with an overall mean of 188 days. He also observed that weight at $1^{\text {st }}$ service was slightly higher in $\mathrm{G}_{1}(9.94 \mathrm{~kg})$ than that in $\mathrm{G}_{2}(9.87 \mathrm{~kg})$ with an overall mean of $9.91 \mathrm{~kg}$. Age at first kidding, Gestation length and kidding interval was not significant $(\mathrm{P}>.05)$ effect on generation (Table 2). Average AFK was higher in $\mathrm{G}_{1}$ (406.6) and lower in $\mathrm{G}_{4}$ (348.85). Kumar et al., (2011) observed that the overall means were 388.88 days and 536.04 days for age at first conception and age at first kidding, respectively which is higher than the findings. Husain (1993) agreed with the results who had shown that the gestation length of BBG goat ranged from 142 to 146 days. Gestation length reported to be dependent on season, year (Gupta et al., 1964) and also kid birth weight and weight of dam at mating (Mishra et al., 1979) not parity Chowdhury and Faruque (2001). Result also showed that $\mathrm{KI}$ was lower in $\mathrm{G}_{4}$ and higher in $\mathrm{G}_{1}$. Husain (1993) agrees with the findings that kidding interval of BBG goat ranged from 210 to 230 days. Jalil et. al., (2016) disagrees with the findings that kidding interval was shorter in $\mathrm{G}_{1}$ (183 days), higher in $\mathrm{G}_{2}$ (196 days) and intermediate (185 days) in $\mathrm{G}_{0}$ with an overall mean of 188 days. 
Table 2. Effect of generation on reproductive traits of HBB goats.

\begin{tabular}{|l|l|l|l|l|l|}
\hline \multirow{2}{*}{ Generation } & \multicolumn{5}{|c|}{ Parameters } \\
\cline { 2 - 6 } & $\begin{array}{l}\text { AFC }(\mathbf{d}) \\
(\text { Mean } \pm \text { SE) }\end{array}$ & $\begin{array}{l}\text { WFC }(\mathbf{k g}) \\
(\text { Mean } \pm \text { SE) }\end{array}$ & $\begin{array}{l}\text { AFK (d) } \\
(\text { Mean } \pm \text { SE) }\end{array}$ & $\begin{array}{l}\text { GL (d) } \\
(\text { Mean } \pm \text { SE) }\end{array}$ & $\begin{array}{l}\text { KI (d) } \\
(\text { Mean } \pm \text { SE) }\end{array}$ \\
\hline G-1 & $259.80^{\mathrm{a}} \pm 18.87(52)$ & $13.23^{\mathrm{b}} \pm 0.47$ & $406.60 \pm 19.02$ & $146.80 \pm 0.78$ & $225.90 \pm 10.27$ \\
\hline G-2 & $236.27^{\mathrm{a}} \pm 11.36(38)$ & $12.09^{\mathrm{ab}} \pm 0.48$ & $381.45 \pm 11.44$ & $145.18 \pm 0.69$ & $217.72 \pm 7.76$ \\
\hline G-3 & $228.65^{\mathrm{ab}} \pm 9.07(27)$ & $11.89^{\mathrm{b}} \pm 0.47$ & $375.33 \pm 9.22$ & $146.66 \pm 0.68$ & $216.11 \pm 8.30$ \\
\hline G-4 & $201.57^{\mathrm{b}} \pm 9.06(23)$ & $10.65^{\mathrm{a}} \pm 0.52$ & $348.85 \pm 9.45$ & $147.28 \pm 0.74$ & $211.42 \pm 10.39$ \\
\hline Sig. level & $*$ & $* *$ & NS & NS & NS \\
\hline
\end{tabular}

$\mathrm{AFC}=$ Age at first conception, $\mathrm{WFC}=$ weight at first conception, $\mathrm{AFK}=$ age at first kidding, $\mathrm{GL}=$ Gestation length, KI=kidding interval, Sig=Significance; Means with different superscripts within the same column differ significantly. ${ }^{*}=$ Significant at $5 \%(\mathrm{p}<0.05)$ level of probability, $* *=$ Significant at $1 \%(\mathrm{p}<0.01)$ level of probability, $\mathrm{NS}=$ Non significant $(\mathrm{p}>0.05)$.

\subsection{Effect of Parity on KBW, KLW and LS of HBB goats}

Results showed that parity had no significant $(\mathrm{P}>.05)$ effect on kid birth weight but significantly $(\mathrm{p}<0.01)$ differ of Kid litter weight and litter size (Table 3). Islam et al. (2016) and Talukder et al. (2010) agrees with the findings that the effects of parity were non-significant $(\mathrm{P}>0.05)$ on kid birth weight. Jalil et al. (2003) observed that birth weight of kids were no consistent trends according to parity in Black Bengal goat. Result also showed that KLW of $3^{\text {rd }}$ parity was higher and lower in $1^{\text {st }}$ parity. On the other hand, LS was increasing with progressing parity with an overall size of 1.69. The present result is in agreement with the findings of Chowdhury et al. (2002), who reported that litter size was affected by parity, age, genetic and environmental factor. They also reported that litter size increased significantly $(\mathrm{p}<0.01)$ as parity progressed. Jalil et al. (2016) reported that average litter size of Black Bengal goat was reported at 1st, 2nd and 3rd parity were $1.31 \pm 0.04,1.81 \pm 0.06$ and $2.05 \pm 0.08$ respectively which is similar with the findings.

Table 3. Effect of Parity on KBW, KLW and LS of HBB goats.

\begin{tabular}{|l|l|l|l|}
\hline \multirow{2}{*}{ Parity } & \multicolumn{3}{|c|}{ Parameters } \\
\cline { 2 - 4 } & $\begin{array}{l}\text { KBW }(\mathbf{k g}) \\
(\text { Mean } \pm \text { SE) }\end{array}$ & $\begin{array}{l}\text { KLW (kg) } \\
(\text { Mean } \pm \text { SE) }\end{array}$ & $\begin{array}{l}\text { LS (No.) } \\
(\text { Mean } \pm \text { SE) }\end{array}$ \\
\hline P-1 & $1.17 \pm 0.031(44)$ & $1.40^{\mathrm{a}} \pm 0.52$ & $1.20^{\mathrm{a}} \pm 0.022$ \\
\hline P-2 & $1.16 \pm 0.02(39)$ & $1.80^{\mathrm{d}} \pm 0.63$ & $1.60^{\mathrm{b}} \pm 0.11$ \\
\hline P-3 & $1.13 \pm 0.02(38)$ & $2.16^{\mathrm{b}} \pm 0.31$ & $1.70^{\mathrm{ab}} \pm 0.13$ \\
\hline P-4 & $1.18 \pm 0.04(33)$ & $1.94^{\mathrm{c}} \pm 0.34$ & $1.90^{\mathrm{ab}} \pm 0.04$ \\
\hline P-5 & $1.09 \pm 0.06(32)$ & $2.26^{\mathrm{a}} \pm 0.41$ & $2.06^{\mathrm{a}} \pm 0.03$ \\
\hline Sig. level & NS & $* *$ & $* *$ \\
\hline
\end{tabular}

KBW=kid birth weight, KLW=kid litter weight, LS=litter size, Sig=Significance; Means with different superscripts within the same column differ significantly. $* *=$ Significant at $1 \%(\mathrm{p}<0.01)$ level of probability, NS=Non significant $(\mathrm{p}>0.05)$.

\subsection{Kid birth weight according to birth type of HBB goats}

From the findings, it was showed that birth weight has significant $(\mathrm{p}<0.05)$ effect on birth type whereas single kid was highest birth weight $(1.21 \pm 0.08 \mathrm{~kg})$ than double kid $(1.15 \pm 0.13 \mathrm{~kg})$ followed by triplet and quadruplet kids (Table 4). Weight up to weaning is the function of birth weight and maternal ability. The kids born singly are heavier than multiple born kids because they get larger amount of milk from their dam and proper space during the fetus development. Parajuli et al. (2014) report significant effect of birth type on birth weight, pre weaning weight, weaning weight, four months weight, six month and weight at nine month in Terai goat. 
Table 4. Birth weight of kid according to birth type.

\begin{tabular}{|l|l|l|l|l|l|}
\hline Parameters & $\begin{array}{l}\text { Single birth } \\
(\text { Mean } \pm \text { SE) }\end{array}$ & $\begin{array}{l}\text { Double birth } \\
(\text { Mean } \pm \text { SE) }\end{array}$ & $\begin{array}{l}\text { Triple birth } \\
(\text { Mean } \pm \text { SE) }\end{array}$ & $\begin{array}{l}\text { Quadruplet } \\
(\text { Mean } \pm \text { SE) }\end{array}$ & Sig. level \\
\hline Birth wt. kg & $1.21^{\mathrm{a}} \pm 0.08(61)$ & $1.15^{\mathrm{b}} \pm 0.13(78)$ & $1.10^{\mathrm{b}} \pm 0.17(43)$ & $1.08^{\mathrm{ab}} \pm 0.13(16)$ & $*$ \\
\hline
\end{tabular}

Sig=Significance; Means with different superscripts within the same row differ significantly. ${ }^{*}=$ Significant at $5 \%(\mathrm{p}<0.05)$ level of probability. Figure in the parenthesis indicates the number of observation, HBB=Hilly Brown Bengal.

\subsection{Kid mortality according to age of HBB goats}

Kid's mortality were higher during 0 to 90 days of age than more than 90 days (Table 5). Kid mortality of Black Bengal goat was influenced by weight of doe, parity, birth weight, milk yield, season, feeding, housing and disease and could be as low as $7.0 \%$ if properly managed (Chowdhury et al. 2002). The significantly higher mortality rate was observed in summer $(13.04 \pm 0.05 \%)$ for the period of 0 to 3 months of age and lower in winter season $(900 \pm 0.02)$. Mortality rate in nucleus breeding flock (NBF) in the present study was higher with the finding of Ahmed (2006) who reported that mortality rate of Black Bengal was 10.5 \pm 2.32 . High mortality of kid on summer may be due to under nutrition and increased susceptibility to diseases. Kid mortality was $17 \%$ in rural scavenging system (Husain 1999) which increased with litter size.

Table 5. Kid mortality of HBB goats according to age.

\begin{tabular}{|l|l|}
\hline Kid age & Mortality $(\%)$ \\
\hline $0-90$ days & $13.08 \pm 0.23(188)$ \\
\hline $90-180$ days & $5.31 \pm 0.41$ \\
\hline$>180$ days & $2.12 \pm 0.63$ \\
\hline
\end{tabular}

Figure in the parenthesis indicates the number of observation

\section{Conclusions}

It may be concluded that kid birth weight, age and weight at first conception of HBB goat were significantly $(\mathrm{P}<.05)$ affected on generation but age at first kidding, gestation length and kidding interval were non significantly $(\mathrm{P}<.05)$ affected. According to parity, kid litter weight and litter size were also significantly affected. It may be suggested that HBB goats need to be conserved and improved further through selective breeding and better management system.

\section{Conflict of interest}

None to declare.

\section{References}

Ahmed HMM, 2006. Studies on the performance of Black Bengal goats, Jamunapari goats and their F1 crosses at government goat development farm in Savar. MS Thesis, Department of Animal Science, Bangladesh Agricultural University, Mymensingh.

Akter S, SS Husain, SA Chowdhury, MM Munzur and GK Sev, 2006. Estimation of variance components predication of breeding value for some economically important traits of Black Bengal goats. Bangladesh J. Anim. sci. 25: 20-26.

Bhattarai N and S Sapkota, 2011. Effect of Non genetic Factors on Weight Traits of Local Tarai Goats under Farmers' Managed Condition. Nepal Journal of Science and Technology, 12: 51-54.

Chowdhury SA and S Faruque, 2001. Improvement of Black Bengal goat through Selective Breeding.Bangladesh Livestock Research Institute, Savar and Bangladesh Agricultural Research Council, Farmgate, Dhaka, Bangladesh, pp.16-17.

Chowdhury SA, MSA Bhuiyan and S Faruque, 2002. Rearing Black Bengal goat under semi- intensive management. 1. Physiological and reproductive performances. Asian-Australas. J. Anim. Sci., 15: 477-484.

Crawford RD, 1984. Assessment and conservation of animal genetic resources in Canada. Can. J. Anim. Sci., 64: 235-251. 
Devendra C and M Burns, 1983. Goats Production in the Tropics (Revised edn.). Tecl Comm., Bureaux of Animal Breeding and Genetics, Commonwealth Agricultural Bereaux, England, pp. 183.

DLS, 2018. Department of Livestock services, Economic survey 2017-18.

Faruque MO, 2010. Farm animal genetic resources in Bangladesh: Part 1. Breeds and varieties of goat and sheep. pp. 12.

Gupta S, T Som and L Bhattacharya, 1964. Studies on gestation length in Black Bengal goats. Indian. Vet. J., 41: 668-672.

Husain SS, 1993. A study on the productive and milk production performance of Black Bengal goat under semiintensive management (Doctoral dissertation, MS thesis, Bangladesh Agricultural University, Mymenshingh, Bangladesh).

Husain SS, 1999. Sustainable genetic improvement of economic traits of Black Bengal goats through selective and cross breeding. Bangladesh Agricultural University Research Progress, 10: 72-80.

Husain SS, P Horst and ABMM Islam, 1998. Goat production and its breeding strategy in Bangladesh. Proceedings of 1st National Workshop on Animal Breeding, Bangladesh Agricultural University, Mymensing. pp. 17-36.

Islam MA, MM Rahman, MA Alam and MA Hemayet, 2016. Productive and reproductive performances of Brown Bengal goat (Hilly goat) at research farm level. Asian J. Med. Biol. Res., 2: 477-482.

Jalil AM, MM Kabir, PM Chudhury and AM Habib, 2016. Productive and reproductive performance of Black Bengal goat under farming condition in Bangladesh. Asian Australas. J. Biosci. Biotechnol., 1: 235-245.

Jalil MA, G Miah, S Akter and MAI Talukder, 2003. Characterization and conservation of Black Bengal goats. Annual Research Review Workshop, Bangladesh Livestock Research Institute, Savar, Dhaka. June-2003.

Kumar A, LB Singh, D Kumar and M Ahmad, 2011. Factors affecting reproductive traits in Black Bengal and Beetal x Black Bengal crosses. Indian Journal of Small Ruminants, 17: 225-226.

Mishra, R.K., Nivsarkar, A.E. and Arora, C.L. (1979). A note on the analysis of gestation length in Sirohi goats. Ind. J. Anim. Sci., 49: 967.

Parajuli A, M Kolachhapati and N Bhattarai, 2014. Effect of non-genetic factors on productive performance of hill goat in Nawalparasi, Nepal. Nepalese Journal of Agricultural Sciences, 12: 198-203.

Talukder MAI, MM Rahman, MA Alam, MM Rahman and MA Hemayet, 2014. Conservation of Farm animal Genetic Resources (FAnGR) at Naikhongchari. Proceedings of the Annual Research Review Workshop, Bangladesh Livestock Research Institute, Savar, Dhaka, Bangladesh. pp. 102-113.

Talukder MAI, MR Hasan, UK Mohanta and MR Amin, 2010. Productive and reproductive performances of Brown Bengal goat at hilly area at Naikhonchari. Proceedings of Annual Research review workshop, Bangladesh Livestock Research Institute, Savar, Dhaka, Bangladesh. pp. 72-73. 